Journal of Social Sciences 4 (1): 42-55, 2008

ISSN 1549-3652

(C) 2008 Science Publications

\title{
How Greece and Ireland Have Been Positioned in the World Developments Since 1945: A French Regulation Approach
}

\author{
Lavrentios Vasiliadis \\ Regional Planning, London School of Economics and Political Science
}

\begin{abstract}
This research analyses how Greece and Ireland have been positioned in the world development since 1945 by using the French Regulation Approach. In particular, this analysis describes three broad periods, notably the Fordist, post-Fordist and the New Economy ones. In each period, apart from the general approach that concerns the world economy transformation, the specific transformations of the economies of Greece and Ireland are also described. It is argued that the different understanding of capitalist dynamism and development by Greece and Ireland, due to their different national characteristics and experiences, had as a result the two countries to implement different policies in order to respond to these changes and consequently differently to take advantage of the new opportunities that have emerged. In this respect, Ireland has advanced a more sophisticated understanding of the dynamics of capitalist development, in relation to Greece and therefore has been able to identify and give preferential assistance to growing sectors (e.g. IT sector).
\end{abstract}

Key words: Regulation theory, foreign direct investment, fordism, post-fordism, new economy, regional development

\section{INTRODUCTION}

In a time period where Foreign Direct Investment (FDI) inflows have reached historic highs, Greece's performance on that field has not followed the same direction. On the contrary, FDI in Greece continue to decrease, contrary to what happens to other developed countries of the EU, like Ireland and Portugal. This tendency has resulted to discussions among scholars ${ }^{[11,14,28]}$ regarding the roots of this cause. In this respect, this research gives a different approach regarding the causes of this downward tendency, based on the French Regulation approach.

More precisely, this research analyses some major developments of the world economy and production since 1945 (end of World War II), by following the approach of the Regulation School. At the same time, the situation of European regional economies (notably Greece and Ireland) in each phase of world transformation is also analysed. The restructuring analysis of the production systems is divided into three broad periods: the first one, called Fordist period, took place from the end of World War II (1945) to the end of 1960s. The second period, called Post-Fordist, took place during the 1970s and 1980s. The last period, called New Economy or even Globalisation era, took place from 1989, with the fall of the Berlin Wall and lasts until today. Although, the analysis of this research has no intention to follow the exact periodisation of the
French Regulation School, this is used as a benchmark in order to develop the above mentioned periodisation (Fordism, post-Fordism, New Economy). This effort tries to give flexibility and to avoid the stiffness of any approach that is used as the basis for the development of an analysis.

The objective of this analysis is to demonstrate the weakness of Greece to understand the dynamics of capitalist development. This will take place by describing how the states of Greece and Ireland have responded to the evolutions of the global economy since the end of World War II, giving an explanation why Ireland has advanced a more sophisticated understanding of capitalist development and therefore was able to identify and give preferential assistance to growing sectors (e.g. IT sector) and policies (pro FDI). The hypothesis is that Ireland very early realised the importance of FDI as a key element for the development of its economy and followed a consistent policy in favour of it, contrary to Greece that has not managed yet to develop a long-term strategy in favour of FDI.

\section{MATERIALS AND METHODS}

In order to answer the question of this research I draw upon French Regulation theory in order to understand the world development and the differential positioning of Greece and Ireland, paying particular 
attention to peripheral Fordism. For this purpose the literature related to French Regulation School, as well as to the economic and political history of Greece and Ireland, has been thoroughly reviewed. By this way I try to combine theory and reality trying to explain major evolutions in Greece and Ireland, caused by international events. The French Regulation School has been adopted as it emphasises the restructuring of the production systems and how this has influenced the positioning of countries in the world power system. At the same time, it considers the state both as a subject involved in regulating the economy and as an object of regulation in its own right $^{[41]}$.

\section{RESULTS AND DISCUSSION}

In order to understand the economic structure of the today world, it is essential to comprehend the developmental logic of the post-war period. The economic boom just after the end of World War II was an illustration of the supremacy within the main advanced capitalist countries of a peculiar pattern of development and of the constancy of a world of configuration that linked them together. Recognising the difficulties of combining theory and history, this research will track the approach developed by the French Regulation School, which first took up this challenge when it tried to understand the rise and demise of Fordist growth regime ${ }^{[16,24]}$. This school put emphasis on the restructuring of production systems, which intensified during the 1980s, indicating an allembracing shift between two historical periods: Fordism and Post-Fordism. It maintains that the processes shaping industrial organisation are broader patterns of development within both core and peripheral countries. More precisely, they consider the history of capitalism as a succession of phases, each differentiated by certain historically developed, socio-institutionally defined structural forms that give rise to distinctive economic trends and patterns ${ }^{[17,33]}$. The framework rests on four key concepts: regime of accumulation, i.e. a recorded set of regular macroeconomic interactions, which includes the critical economic conditions for the operation of the productive system (technology, organisation of the labour process, relations between the departments of production) ${ }^{[1]}$, mode of regulation, when any uncertainty of the investors about the future coherence of the regime of accumulation is eased by regulatory mechanisms, institutions, compensatory mechanisms and information systems ${ }^{[44,49]}$, mode of socialisation, i.e. the establishment and consolidation of a mode of regulation, which is heavily dependent on the political sphere. This means that different social groups, regardless of the divergences in their interests and their economic inequalities, over the long-run make up a nation in which power relations are perpetuated without major dispute. This stable system of relations of domination, or for some others, of concessions among different social groups (dominant and subordinate) is called social block ${ }^{[44]}$ and the role of the state, which is vital because it reinforces the institutionalised compromises, asserts its monopoly of institutionalised violence, defends the currency, enforces legislation and manages relations with other nations ${ }^{[44]}$.

According to Boyer ${ }^{[15]}$, a prominent regulationist, institutional differences at the nation-level are very important, but, in the long-run, economic developments depend upon the dominant mode of regulation in each historical era. Thus, whereas, especially OECD countries, operate under a common environment, differences at the mode of regulation at the national level may explain their relative competitiveness and growth rates ${ }^{[15]}$. This is a very important argument for the evolution of this research, as at the end our intention is to clarify how, through different modes of development, the different national institutional regimes of Greece and Ireland were driven towards the dominant mode of regulation, which was their more and more integration into the world capitalist system. Thus, the following structure of this research has two tasks. The first one is to describe the world developments, driven mainly by USA and some large European countries, since the end of WWII. The second task is to describe how the two countries in question and particular their institutional regimes, were affected by these developments and what were their (re) actions to them.

Thus, the immediate post-1945 era was characterised by the Fordist mode of development originated in the United States. More precisely, the Fordist industrial paradigm included the Taylorist principles of rationalisation, plus constant mechanisation. Aglietta ${ }^{[1]}$ defines Taylorism as the sum total of those relations of production internal to the labour process that tend to speed up the completion of the mechanical cycle of movements on the job and to fill the gaps in the working day. Taylorist rationalisation was based on a separation of the intellectual (i.e. research and development, design and the scientific organisation of work) and manual (i.e. unskilled operational tasks) aspects of labour. The establishment of the Taylorist-Fordist labour process was supported by a transition in the mode of regulation of capital-capital relations away from full competition towards oligopoly. A qualitative increase in the intensity of capital, the rise of finance-dominated trusts 
and the emergence of modern firm allowed for greater inter-capitalist control of competition, markets and in general of the overall investment environment ${ }^{[17]}$.

After the end of WW II, Taylorist management techniques were incorporated in most industries both in the USA and Western Europe. This was also favored by the implementation by the USA of the Marshall Plan. The Plan aimed to give to the countries of Western Europe (and Japan) that had suffered from the war those financial and technical means that would allowed them to catch $\mathrm{up}^{[67]}$. As a result of these new management techniques a vast deposit of homogenous and mobile labour-force, both controlled and submissive to capitalist labour discipline, was created. The mass migration of workers particularly contributed to the growth of this pool of labour. Additionally, there was a relatively regular rise in real wages, which was the result of a constant fall in real social wage costs due to the increase in productivity ${ }^{[1]}$.

Whereas this was the case for the United States and the large European countries (and Japan), what about peripheral Europe and particularly Greece and Ireland which are at the focus of this research? As mentioned above Fordism contributed to Taylorism by incorporating the collective knowledge of the labour force into the machine system itself. Additionally, the Fordist regime of accumulation stimulated not only a rapid increase in the volume of investment per head but also a growth in per capita consumption. Within this context, the role of peripheral countries was very limited. The reason was that Fordism was based on the principles of mass production and mass consumption. The less wealthy peripheral countries could not fulfil this principle. They could not produce massively, because they could not consume massively. The United States of America in their effort to help peripheral countries to develop some level of mass consumption initiated different forms of aid (the most known one is the so-called Marshall Plan) so that in the long run the European markets, including the peripheral ones, could consume more American products as a result of the improvement of their quality of life.

But, since the mid-1960s a slowdown in real social wage costs was observed, which challenged Fordism as the principle mode of management of wage-labour. Aglietta $^{[1]}$ describes this situation as a crisis of the reproduction of the wage relation, which affects methods and goals of production, as well as modes of life. In particular, it was the slowdown in the rate of increase in productivity that led to a rise in the real social wage, which in turn led to the crisis of Fordism. The full employment and the rising wages that were characteristics of the post war boom, had led to the trade unions being quite powerful. Precisely, Aglietta ${ }^{[1]}$ (1979: 162) argues that the root of the crisis of Fordism was the intensification of class struggles at the point of production. Whereas, initially in the post war boom it was possible for wages and profits to raise simultaneously, at that time where the rate of increase in productivity declined, profits could only increase by decreasing wages or vice versa. If labour secured wage increases this would have an adverse effect on profits. But, the entrepreneurs would not easily accept this. At the end the crisis extended to the whole spectrum of relations of production, causing disturbance to the Fordism regime of accumulation.

As a result, during the 1960s the Fordist mode of production entered into crisis ending up to its collapse. The main reason for this was the crisis of mass production model, which took place at both micro-scale and macro-scale. According to Leborgne and Lipietz ${ }^{[44]}$, the cause was not a new global crisis of underconsumption, or a problem of supply side. Mainly it was the succession of two destabilising events, i.e. the expression of internal causes (notably the crisis of the model of development itself, principally on the supply side) and external causes (notably the internationalisation of the economy, which jeopardised the national management of demand) ${ }^{[44,26]}$. In particular, since the early 1970s, rates of output and productivity growth in developed countries have been halved in comparison to the post-war golden age. The increase in oil prices that took place in the early 1970s accelerated the crisis in the developed countries. In the vast majority of the western world (especially in its most developed countries) a decrease on the level of demand took place. But, output did not follow a similar trend. On the contrary, large amounts of money were engaged in stocks of goods and material, paying less attention to the quality. At the same time, mass unemployment and widespread social exclusion have appeared and inequality has increased. The crisis created was so acute that even the Keynesian economic policies, contrary to the past, proved entirely incapable of putting an end to it.

This increase in oil prices, plus low growth in western economies led to banks having large amounts of oil money seeking investment opportunities. As a result, many developing countries, especially from Latin America, borrowed in order to invest in industry, with the intention of exporting in order to pay back the loans ${ }^{[2]}$. Towards this direction the developing countries had the support of international organisations and banks. Thus, the collapse of Fordism in the late 1960s produced a new pattern of capitalist development. In particular, the large firms of the Western World in their 
attempt to raise productivity by expanding the scale of production, as well as to recover their profitability, started seeking refuge in the Peripheral Countries or Newly Industrialised Countries, where ample cheap labour existed and where the organisational forms of Fordism would continue to be economically viable ${ }^{[8,45,37,38]}$. But, in these Newly Industrialised Countries, only selected branches of production, or selected phases of the manufacturing process of one product were transferred. Organisation and control of production processes remained to the core industrialised countries $^{[7]}$.

But in order for the large Western corporations to be able to invest directly, i.e. via FDI, in peripheral markets, they should overcome two obstacles. The first one was tariff barriers designed to protect local industries by foreign firms. Another problem was that certain socio-economic and political conditions should exist in peripheral countries. A very important condition for the expansion of the Fordist mode of production to the peripheral countries was the existence (in the periphery) of political regimes whose ruling classes supported a free but disciplined workforce and was determined to use it. But, this was not a condition that existed everywhere. In all these peripheral countries the available labour force had only recently moved from land occupation and its transformation to an industrial worker was not an easy task. This was a difficult process that involved the mobilisation and stabilisation of industrial discipline.

Thus, the expansion of multinational corporations into new markets and the changing nature of the economic, social and political conditions within these markets was named by Lipietz ${ }^{[45]}$ as Peripheral Fordism. The characteristics of the markets of Peripheral Fordism include, among other things, the participation of middle class in the consumption of durable goods, exports of cheap manufacturing to the centre and a negative balance of payments. In order to improve balance of payments, sources of finance were found within the old division of labour, from the promotion of raw materials exports and from borrowing from international capital and money markets. These loans were pledged against potential income from traditional exports (including tourism, petroleum and emigration), the promise of work, which in turn depended upon the profitable inauguration of new production processes in the developing countries, upon the existence of markets for their future production and lastly the recycling of borrowed capital to buy capital commodities from the North. Another form of financing of the peripheral countries had been channeled through direct investment. But because the financing through direct investment was inadequate countries started to borrow from the international capital and money markets. In particular, between 1967 and 1980, the funds repatriated by emigrants and tourism, accounted for 52 per cent of Greece's trade deficit. On the other hand, Ireland had already initiated an aggressive policy of FDI attraction and development through exports. For all countries the rest of the deficit was covered through borrowing $^{[45,8]}$.

But according to Arestis and Paliginis ${ }^{[8]}$, peripheral Fordism as developed by Lipietz does not include regulation and accumulation, two fundamental features of Fordist era. More precisely, Fordist accumulation in the developed countries is the result of a historical process where the necessary institutional framework has already been put in place. This process had the support, at least in Europe, of a strong trade union movement, giving rise to the development of corporate philosophy of the western societies. On the other hand, in the case of the peripheral European countries, production was dominated by multinational enterprises that were externally controlled and were not fully integrated into the national economies. Moreover, their institutional framework was either absent or illdeveloped and the relations of the state, capital and trade unions were not the appropriate ones in order for the regulatory policies of the developed countries to be implemented in the European periphery.

As a result the role of international capital in economic development was ignored. In all countries of the European periphery (namely Southern Europe and Ireland) economic measures that made the entrance of foreign investors very difficult were initiated. Many of these measures were contradictory and were taken due to a political interest of the then party in power. The main reason for this was the desire of countries for an autonomous growth. In Ireland, from 1932 to the late 1950s, high level of protectionism was introduced. In particular, according to the Control of Manufactures Act of 1932, Irish people had to control 51 per cent of the voting shares in manufacturing firms. The aim of this Act was twofold: first, to protect the primitive Irish industry and second, to block UK firms from taking advantage and setting up companies in the protected Irish economy capturing by this way market share from local producers ${ }^{[51]}$. This policy resulted to an almost negligent amount of export production and Irish industry became uncompetitive and weak, producing poor quality of products. The consequences of protectionism were revealed after 1960, when the first foreign industries were established in the country.

Similarly, in Greece after the end of the civil war in 1949 there was a short period of weak governments that emerged from continuous elections. The first strong 
government emerged in 1952. The first measures for the restoration of the Greek economy were the lifting of many price and import controls, the drastically devalued drachma and reduced interest rates. This policy continued during the next years accompanied by investments in the infrastructure of the country, particularly in the road network. During the whole period, since the end of World War II and until the mid 1970s, Greek policy was characterised by increasing role of the state in the Greek economy and society. In particular, a large number of government agencies were created, union activity was heavily controlled and the banking system was strictly regulated. However, the role of the state still remained small ${ }^{[6]}$. Additionally, during this period the Greek economy was characterised by an over-concentration of almost all economic activities in Greater Athens area that had as a result the relative underdevelopment and even backwardness in the rest of the country ${ }^{[36]}$.

When the crisis of Fordism started, Greece and Ireland being next to the European core were obvious places for the expansion of multinational corporations. International capital was seeking places where it could produce and distribute its products to the large markets in safety and rapidly. But, this expansion could not take place without any preparation for the following reasons: first, since the end of World War II Greece had emerged with industrial and social structures that were archaic compared to the (dominant) American model. Second, contrary to Greece, by the 1960s Ireland could not be characterised as a Newly Industrialised Country according to the criteria set by the World Bank as it was in a more severe economic and social situation than NICs.

Nevertheless, in Greece and Ireland the processes leading to the development of industrial discipline had started since the mid-1950s, i.e. before the crisis of the Fordist period. In Greece there was a significant economic growth during 1950s and 1960s. But, despite this economic growth mass emigration continued. According to King and Donati ${ }^{[42]}$, emigration was seen as the causal factor behind economic growth. Additionally, cheap labour in Southern Europe favoured the attraction of FDI, especially in the manufacturing sector. Nevertheless, the overall outcome was the deterioration of the domestic economic situation, which was characterised by rising imports and declining exports. This in turn led to a deteriorating political situation, which was the result not only of the bad economic conditions, but also of the weak institutional forms.

At the same time, the 1960s was the decade where the dictatorship emerged in Greece. During the dictatorship significant industrial expansion took place.
The main reason for this was the new political conditions created with the emergence of the dictatorship. The leaders of the new regime were keen to accept foreign investors in the country, especially American ones, as this legitimised their regime. But, this was not accompanied by a similar upgrade in the quality of life for the people of Greece (and thus in their ability to consume more). For example, prosperity that was previously resulted in a measure of tolerance for the dictatorship was questioned and the sudden fall in living standards stimulated civic unrest ${ }^{[6]}$. When the first democratic government emerged with the collapse of dictatorship, the labour force in Greece was really keen to accept the establishment of foreign capital in the country, often under dead-weight rules. The result was the creation of an industrial economy, which had Fordist tendencies, even if it was not yet Fordist as such. In short, they brought into line with a European version of the American model ${ }^{[45]}$.

On the other hand, in Ireland, which was suffering from massive unemployment and massive emigration, there was a national consensus for changing the model of development. Already, the coalition government of 1954-57 began to talk to the World Bank and International Monetary Fund. Despite the internal political situation, that for many decades the ideology of independence and self-sufficiency was the dominant one, Ireland had received nearly 150 million pounds in aid under Marshall Plan by $1950^{[64]}$. But, in comparison to Greece, in Ireland there was no need for the establishment of a dictatorship for three main reasons: the first reason was the low social and economic conditions of the population as well as its poor industrial base leaving practically the Irish society with no other choice but to accept any new way of development process. Second, it was the close social and cultural connections with United Kingdom, a country that had no history of establishment of a dictatorship as a solution to social and economic problems. Third, Ireland did not have a socialist/ labour party. Neither of the two main parties was anticapitalist. Thus, in 1958, the Irish government initiated the establishment of a formal economic planning together with an official declaration of the abandonment of protection and import substitution policies in favour of export-led growth. This date is considered as a turning point for the future development of Ireland. About one decade later this policy was principally geared towards trying to attract foreign multinationals into the country, by not only offering generous grants, but also export tax relief ${ }^{[12,51]}$.

Thus, according to the World Bank classification in that era (end of 1960s) Greece was considered as Newly Industrialised Country, with higher growth rates, 
particularly in industry, than the old industrial countries. But, this was not the case for Ireland, which in 1960s was still far from being considered as a Newly Industrialised Country (although economic growth reached its highest levels ever). In particular, in the early 1960s Ireland was still a poor economy with limited industrialisation and low rates of economic growth. In the case of Ireland, Perrons ${ }^{[55]}$ argues that the development of neo-Fordist techniques, i.e. the introduction of the more automated labour processes, based on electronic information systems with automatic feedback mechanisms and in combination with the entrance of the country in the European Union (1973), improved the position of this country as a potential FDI location. Thus, since the early 1970s, Ireland started to attract an increasing number of branch plants of multinational enterprises. The production of these branch plants was (and still is) mainly exportoriented $^{[55,29,66]}$.

Summarising the developments in the world production processes and its effects in peripheral countries and more precisely in Greece and Ireland, I argue that in the 1960s the two countries had different forms of integration within the international economy. The above arguments show that, in relative terms, Greece is closest to the old international division of labour as it was producing and exporting primary goods. On the other hand, Ireland was closer to the New International Division of Labour. This meant that some peripheral countries were no longer limited to producing just raw materials and food supplies for markets in the industrialised world or even manufactured goods for the domestic market, but have been further drawn into the framework of the world economy, not through interstate relations of colonialism, but in accordance with the exigencies of the framework of international co-operation. Within this New International Division of Labour, only specific manufacturing activities are decentralised. However, this is not a static situation and certain capital goods industries, e.g. iron and steel production, were expanding in these areas, although machine tool industries were still almost exclusively confined to the more mature industrialised economies. In particular, since the early 1970s American, European and Japanese firms located in Ireland large plants that were using Taylorist and Fordist labour processes giving rise to the super-imposition of a more modern industrial system $^{[55,56]}$.

With the collapse of Fordism a new stage of capitalism began to emerge during the 1970s. A unique definition of what post-Fordism is cannot be given, as it has been subject of discussion among many scholars. There have been different interpretations of what postFordism is, which respectively propose different scenarios of the future development of the global system. Thus, instead of referring to different scenarios of how the world transformed with the collapse of Fordism, a reference to some evident points of this change will be given. Thus, the post-Fordism world took the following form since the beginning of 1970s.

According to Aglietta ${ }^{[1]}$, neo-Fordism is a new mode of production aimed to meet the crisis in such a way as to safeguard the reproduction of the wage relation. At the centre of this regime of accumulation is automatic production control or automation. Capitalism benefits from this because flexibility in the location of production units allows it to break up large workingclass concentrations and create an environment that minimises convergence of struggles at the point of production. New systems of production, including contracting-out the manufacture of specialised commodities and services and the ability to source supplies and services wherever they can most efficiently be provided, develop this flexibility ${ }^{[13]}$. At these new conditions, workers are no longer subjected to a constraint of personal obedience, but rather to the collective constraint of the production process. Within this spectrum, trade unions that had become very powerful, due to the Fordist production processes, started to be considered as rigid and unworkable in the new flexible and more decentralised production system. On the other hand, Sayer and Walker ${ }^{[62]}$ as well as Harvey ${ }^{[33]}$ argue that this transition to a new era does not indicate fundamental departure from known workings of industrial capitalism (i.e. Fordism industrial paradigm). Rather, they pivot on the shifting division of labour and new methods of industrial organisation. Fordism still persists over wide areas of industrial sectors despite the fact that it has not remained static.

Regarding the new geopolitical conditions created with the crisis of the Fordist mass production regime, Lipietz $^{[46]}$ argues that the post-Fordist world is organised into three continental blocs. The three blocks are Asia and the Pacific around Japan, the Americas around USA and in Europe around Germany. Within these blocs there are countries, which are very unequally developed (core vs. periphery). In particular, peripheral economies generally had in common a number of weaknesses, including infrastructure deficiencies, isolation from the core and marked regional disparities. Furthermore, their economic tradition can restrain development, such as the largescale export of labour and the centralised and 
bureaucratised political structures. A characteristic of these blocks is their internal mobility, i.e. the power relations between countries can change at any time.

Thus, in the late 1960s and early 1970s, the vast majority of the advanced capitalist countries responded to the first disturbances of the post-war boom by trying to reinforce the existing system of macro-economic control and mass production. Firms kept following the logic of mass production and tried to cut costs by increasing economies of scale: products intended for domestic sale were standardised for sale in world markets, e.g. the world car introduced by Ford and General Motors. Production was re-organised to allow decentralisation of labour-intensive processes to lowwage areas ${ }^{[61]}$.

In particular, there were two main corporate responses in the crisis of Fordism. One was conglomeration; i.e. large firms tried to avoid risks in their home market by diversifying their production or by taking over firms in different sectors. The second way was multinationalisation. The aim of multinationalisation is to attain economies of scale no longer obtainable through the extension of the domestic market. This aim is attained by producing a good that can be sold in many national markets at the same time $^{[58]}$. Multinationalisation was the typical response of American automobile corporations. An essential requirement of this strategy was the extension of the operations of the firm into at least some parts of the developing world. At the same time they had to defend their market position in metropolitan countries.

Conclusively, it can be argued that the crisis of Fordism in Europe created new opportunities for a reregionalisation of the economy and new developmental possibilities for peripheral countries (and regions). Indeed, a large number of firms were forced, most of which were dealing with modern manufacturing activities, to expand themselves into the European periphery and other Newly Industrialized Countries. These countries would offer the needed expanding margin of demand in order to achieve further economies of scale. But, one important precondition for this was the maintenance of the demand level for consumer goods in the advanced capitalist countries in high levels. This was the case especially with the American car corporations.

The choice of the large Western firm to expand their activities into the less developed countries had as a result, since the early 1970s, the serious exposure of European peripheral countries to multinational capital. But, in order to remain competitive, especially as a low wage location for investment, in relation to the developed countries, they should maintain their relatively low cost living conditions ${ }^{[8]}$. More precisely, Greece and Ireland, during this long and painful time period, struggled to restore competitiveness, either by labour cost reductions or by innovations and quality ${ }^{[16]}$.

Thus, in Ireland, during the early 1970s there was an important change in regional industrial policy, with the implementation of the Regional Industrial Plans for 1973-1977. This change coincided with the Irish membership in the European Union, which gave Irish products easier access to the European markets. It also increased the attractiveness of Ireland as a location for manufacturing investment, mainly for the firms outside the EU, characterised by cheap labour wages and proximity to the European markets ${ }^{[30]}$. The aim of these industrial plans was to ensure the maximum geographical dispersion of new industrial development, by the Irish governing body for industrial policy, the Industrial Development Authority (IDA). The same approach continued in the Regional Industrial Plans for 1978-1982. Since 1982, there was a distinct change in Irish industrial policy. Their focus changed to trying to attract hi-tech foreign-owned industry into Ireland, while regional dispersion of these foreign firms became of secondary importance. This industrial policy has remained, with small changes, until today ${ }^{[12]}$. Thus, these two decades were particularly important for Ireland as it was transformed to a really open economy in terms of international trade and started to attract the first multinational enterprises. But, as Sweeny ${ }^{[64]}$ argues, the growth of the Irish economy since 1977 was based on massive public spending financed by borrowing. According to the same author, this was one of the greatest mistakes of Ireland in the whole 20th century as it took a long time to get public finances back on track.

As far as Greece is concerned, during 1970s and 1980s, certain, domestic and international, events of the 1970s and 1980s marked its development process. First of all, in 1974 the Greek dictatorship collapsed. But this collapse coincided with the occupation and loss by Greece of the northern part of Cyprus by Turkey. This led to an anti-American and generally anti-Western, sentiment to spread all over the country. Additionally, the first world-oil crisis affected the Greek economy and society deeply and caused an extended post-1974 period of crisis and restructuring ${ }^{[43]}$. Thus, after the collapse of dictatorship, a nationalisation process took place. As a consequence, since the mid-1970s, the entire Greek industrial sector had suffered serious decline. In that time most industries in Greece were small in size and unable to compete with international capital. The second world oil-shock (1978-1979) accelerated the tendency of change. The situation 
became even worse after 1979 , continuing this trend in the first half of the 1980s. However, it was not until 1981, when the Socialist party PASOK came into power that the public sector really matured. Contrary to the other Western countries, in Greece there was not a restrained union leadership willing to enter into negotiations with the State. Moreover, when the socialists came into power, one of their aims was to further expand their influence within the labour movement and did this by continuing to support radical policies. As a result, there was an expansion of the public sector mainly by nationalising a host of unwanted bankrupted firms. According to Caloghirou, Voulgaris and Zambarloukos ${ }^{[18]}$ in that time, 48 firms and their subsidiaries, with a total of 30.900 employees, were nationalised and placed under the control of the Organisation for the Readjustment of Firms (OAE). These provided 4,5 per cent of total employment in manufacturing, but for certain sectors the percentage reached 30-40 per cent. Thus, in the middle of 1980s, the Greek economy was characterised by high taxation, high inflation, a ballooning public deficit and a large public sector. Contrary to the rest of the Western World, restructuring and adjustment policies did not start to be applied during this decade ${ }^{[54,18,43]}$.

As a result, the post war evolution of Greece was characterised by three distinct features that remain so today. The first concerns the course of employment change. Contrary to Western Europe where there was a horizontal transition from the agricultural sector to the industrial and then to the service sector, in Greece this transition was from agriculture straight to the service sector. Although there was a time-period, mainly during the 1950s and 1960s where employment in industry was increasing, Fordist assembly-line production and Taylorist work practices, never became dominant as in the Western European countries ${ }^{[42,43]}$. The second distinct feature is the markedly uneven development of Southern Europe between the 1960s and 1980s. In Greece, a polarization of population and development around Athens, with a subsidiary pole in Thessaloniki took place. Finally, despite the significance of a variety of policies and processes, such as foreign investment and EC regional aid, in the development of Greece, most important has been the endogenous expansion of the informal sector. To these informal work practices was based the post-Fordist flexible accumulation $\operatorname{regimes}^{[42,43]}$.

Consequently, in a time period where large Western firms were looking for new countries, characterised mainly by cheap labour force, only Ireland had taken a clear decision for changing its policy towards a more open economy that would allow foreign investors to come into the country. Already, since the early 1970 s, the new foreign firms were contributing much to the economy of this country ${ }^{[64]}$. Whereas in most countries FDI was related with oligopolistic competition, this was not the case with Ireland where the foreign enterprises were almost exclusively export-oriented ${ }^{[50]}$. On the contrary, in Greece foreign investors were confronted with suspicion and even negatively. Despite Greece's early entrance to the EEC, the anti-Western sentiment remained strong (not only at the level of the population, but in particular at the level of the political leadership), which in combination with the geographical isolation and other economic problems resulted in keeping the inflows of the foreign capital low and what took place was mainly of an import-substituting nature ${ }^{[8]}$. It was not until the end of 1980s, with the defeat of PASOK, that Greece tried to introduce measures for improving macroeconomic indicators and adopting policies towards a more open economy.

The 1970s and 1980s had been a very hard period where countries re-organised their regulatory framework and the large Western firms searched and found new locations in order to maintain high their levels of production. But, during the 1990s with the rise of new technologies (computers, telecommunications, electronic mass media, etc.) and the globalisation of business activities a new era, very often called information era or new economy, has emerged ${ }^{[59]}$ bringing further changes in economic and social preferences. Some authors ${ }^{[32,37,63,48]}$ consider the new economy as a sequence to the Fordist era. They argue that the roots of the information economy are found in the inherent deficiencies of the Fordist production regime, i.e. the expansion of State involvement in the economy and society of much of the western world. Industrial innovations, the bureaucratic and corporate organisation of society, as well as new demands for education and social services increased the need for rapid access to information, but also to alternatives to mass production processes ${ }^{[63,37,38]}$. But, according to Boyer $^{[16]}$, the emergence and diffusion of information and communication technologies (ICT) meant the functioning of a totally new productive paradigm. This new productive paradigm was marked by the prompt perfection in the quality, combined with a respective decline in prices of ICT equipment and software, the convergence in communication and computing technologies, as well as the growth in network computing $^{[59]}$. In that time there was an enthusiasm to the world media that was transferred to the public, 
because of the new opportunities that started to emerge with the internet and telecommunications in general. All this process became even more evident and created huge expectations to investors and policy-makers in the late 1990s when stock markets boomed, powered by ICT and dotcom firms. At the same time, productivity and economy figures increased, with higher rates than the past 10 years, in the United States, followed by the European Union countries and the rest developed world.

Although this is partially right I argue that the New Economy era would not be possible without postFordism. Some authors ${ }^{[37,63,47]}$ tend to describe a transition from Fordism to the New Economy era, without taking into consideration the time that states, organisations and companies needed in order to reorganise themselves and find a new regulatory framework. They do not refer to what period follows the crisis of Fordism, which led to the opening of national states, as well as to the search by companies for new locations. According to their argument these changes should have taken place during the Fordist period. But is this the case? I argue that this period of re-organisation of firms and nations is the so-called post-Fordist one (as does the Regulation approach). With the emergence of the New Economy era, a new institutional framework also created in which economic actions take place ${ }^{[31]}$. The relationship of powers between the state, capital labour and the consumers/ citizens changed in this new era, as it is going to be shown in the next lines.

But, contrary to the French Regulation School, which supports the idea that post-Fordism remains until today, I argue that Post-Fordism has been the transitional stage for national and supranational states, as well as for companies in order to re-organise themselves. Besides, the post-Fordist era is far from being characterised as a prosperous period for the countries. I argue that the New Economy era started when national and international markets were stabilised and as a consequence a new prosperity period began in which the needs of consumers and companies started to grow up (similar to the product life-cycle theorem). Then new technologies started to become available to the masses (e.g. a significant drop in telecommunication prices, popularisation of the internet) creating new expectations for the companies that produced and served the world population. Companies in order to respond to the new demands as well as to remain competitive (e.g. they had to invest more and more funds to R\&D) started to grow in size, either by continuing to invest in different locations all over the world, or by merging with other firms in the same or relative to theirs sectors.

In support of the just-mentioned arguments are the following words of Boyer ${ }^{[16]}$ :

"A recovery of growth has been frequently assumed to depend on the emergence of a totally new growth regime: its characteristics would include cost and price moderation, increasing exports, spill-over to investment and consumption, recovery of demand and accumulation of growth through interaction of competitiveness and domestic demand".

But what exactly are the most notable changes of the New Economy era in relation to the post-Fordist one, that justifies the argument of a new periodisation? The rise of ICT technologies has created a new situation where new business practices and economic policies are facilitated. As a result flows have become relatively dominant at the expense of places ${ }^{[65,31]}$. Thus, the management and disposal of knowledge and innovation to different locations (via flows) have increased in importance in relation to the old characteristics of countries, such as low labour costs.

Another notable change of the New Economy era is that national governments seem to lose pace in relation to other forms of governments at lower (e.g. region) or higher (e.g. international organisations) levels. According to Sabel ${ }^{[61]}$, there is a tendency of upgrading the region as an integrated unit of production. To this have contributed the successful examples of industrial districts in Italy (e.g. the case of the Third Italy), West Germany (e.g. the industrial districts in the Land of Baden-Wurttemberg), United States (e.g. with the cases of Silicon Valley and Los Angeles) and elsewhere in the world. If we take the examples of these successful regions into account we can see that local institutions become equally important with the central governments and institutions as far as the policies pursuing the attraction of FDI. At the same time, there is another tendency where central governments continue to give away some of their powers towards international organisations, such as European Union and NAFTA. By this way, particularly developed nations have aggressively promoted globalisation and the opening of new markets to provide cheaper production inputs ${ }^{[31]}$.

But, this does not mean that nation-states have become obsolete. There are other authors, such as Dicken $^{[23]}$, who argues that national states still remain key players in the contemporary global economy and Porter who argues that the nation increases in significance because it is the source of the skills and 
technology that support competitive advantage. Moreover, the opening of borders, through globalisation, make nations even more important ${ }^{[60]}$. In a similar way of thought, Harvey supports the argument that the nation-state is loosing power as a centre of authority in the age of globalisation is a silly notion. The reason is that currently the nation-state is more devoted than ever to creating a good business environment for investment especially against the labour movement, e.g. by cutting back the social wage. The only evident point where the national-state seems to have lost power is in its relations with capital. Its ability to regulate the mechanisms of allocation of international capital has overrun the national level ${ }^{[32,33]}$.

In any case, these processes of restructuring have had diverse regional development implications, reinforcing the position of some of Europe's strong countries and regions, offering new growth opportunities in others and triggering decline elsewhere. This reshaping of the map of regional growth and decline has been associated with wider changes in the character of contemporary capitalism. As mentioned before, the crisis of Fordism forced companies to search for new locations where the organisational forms of Fordism would continue to be economically viable. At the same time, national states recognised that they could no longer maintain full employment via Keynsian policies. Hudson argues that this recognition of the limitations of state's capacities to counter market forces led to a search for new neoliberal macro-scale regulatory models. In Europe, for example, national states embraced the European Union as a supranational state, which simultaneously encourages globalisation and at the same time is a place of resistance to it. More precisely, on the one hand EU adopts policies to promote globally competitive companies (via support for $\mathrm{R}$ and $\mathrm{D}$, a permissive attitude to intra-EU $\mathrm{M}$ and As, etc.) and on the other hand seeks to promote social and spatial cohesion and equity within EU. These two policies have influenced corporate restructuring and patterns of territorial uneven development ${ }^{[37]}$. By this way the EU can, in specific circumstances, influence corporate (dis) investment strategies and geographies of production. In other words, what Hudson argues is that globalisation is the result of a series of policy decisions by supranational and national states. Globalisation is based on their participation in changing the international regulatory framework via institutions, such as the IMF, the World Bank, GATT, etc. ${ }^{[37,39]}$. More precisely, globalisation is the process that allowed the New Economy to develop. Within this spectrum, the specific characteristics of places, as well as the territorially embedded institutions are of particular importance in determining competitiveness among states and regional development strategies.

Within this status all small economies, like Ireland, Greece and others have little choice in the era of globalisation but to encourage a policy that favours the attraction of foreign capital through FDI. In any other case, they face the risk to being placed in the margin of the world. Unemployment in recent years has become, probably, the number one problem for the majority of the countries all over the world. In this respect, FDI is a major vehicle to battle unemployment. The whole analysis gives evidence that the world, during the last fifteen years, is moving towards one single direction, which is the liberalisation of the national economies, especially the small ones. This seems to be true. According to $\mathrm{OECD}^{[53]}$, industry in small countries is much more globalised than that of larger countries. On the other hand, there are major disparities between these countries. These could be attributed to differences in industrial development.

Within this spectrum countries that have spent long periods pursuing interventionist and even nationalist economic strategies in order to restore their competitiveness have, to varying degrees, acknowledged the need to break out of the narrow domestic market and seek economies of scale in the larger international marketplace. This new neo-liberal macro-scale regulatory model further eroded national state's limited powers. This model was also inserted in the Eastern European countries as a form of shocktherapy, which conditioned the way in which they were accepted into the wider global economy and redefined the map of locational possibilities for production within Europe ${ }^{[37,38,39]}$.

This new growth model is associated with the increased mobility of capital, goods, services, commodities, information, people and communications across national frontiers, combined with labour-market flexibility, price stability and credit to sustain consumption in high levels. Within this spectrum, the capacity of each country to adopt and implement such a developmental model would be a determining aspect in macroeconomic performance and would place the country in a hierarchical world economy governed, as Boyer $^{[16]}$ argues, by the diffusion of a financialised growth regime.

For Ireland and Greece, all small economies and members of the European Union, globalisation is a very important phenomenon. This is because, among other things, both countries are potential hosts for direct investment from multinational corporations. Within this context of globalisation, national economies are more 
and more constituted out of three interacting, but empirically unique modes of integration into the world economy. The first one is that of attracting FDI and to a limited degree embedding it in the local economy. The global goes local. The second and most surprising in the context of Irish economic history and Greece to a lesser extent, is the appearance of a local network of native firms that have become increasingly integrated into international business and technology flows and have been highly successful in international markets. The local goes global. Third, a series of national neocorporatist social partnership agreements, in both countries, since the mid-1980s have generated a stable macroeconomic and financial environment that has underpinned industrial transformation, while mediating the relationship of unionised workers and welfare recipients to the global economy.

During the 1990s, Greece and Ireland in different ways managed to take advantage of the new conditions created by the expansion of globalisation. In particular, Ireland profited most from this situation, as it became a major software producer, as well as a major location for investment in pharmaceutical sector and especially in biotechnology. On the contrary, Greece, despite its efforts to adjust the productive capacity to market competition $^{[18]}$, failed to attract significant amounts of FDI, but on the contrary its position has deteriorated. The spread of globalisation coincided with a very important evolution within the European Union. This evolution took place from 1992 when the Single European Market became fully effective, removing many non-tariff barriers between EU Member States and abolishing all capital control within the European Union. In practice, among other things, this meant that the peripheral countries of the EU were even more open to international competition. Additionally, they were better able to use the comparative advantages they had, or had not, created all these years in order to attract FDI. For outsiders but also for insiders, Ireland and Greece would be considered just as a location for investment targeting the whole EU market and not just the local market of a specific country. Additionally, since the collapse of Communist regimes in 1989, much of the attention of the European Union was focused on Eastern European countries. This also resulted to a redefinition of relationships with Mediterranean countries $^{[38]}$.

Conclusively, the new evolutions caused by the New Economy affect the countries of the European periphery as well. It is highly debatable whether less powerful countries have the option to follow a different economic policy than the one, which is predominant and promotes the openness of the national markets, the deregulation of the labour market, etc. If they do so, they face the risk to become marginal, not only in terms of economics but also in terms of politics. In this respect, countries like Greece and Ireland, which participate almost in every Western alliance and are integral part of the western world probably have only one economic policy option: the one that favours the openness of their national market. How quickly each country adapts itself to the new conditions and how it decides to soften the negative effects of globalisation, which definitely exist, is also a national political decision, which of course also requires a wider social acceptance.

\section{CONCLUSION}

A major task of this research was to document the processes of economic and political restructuring within the context of changing institutional arrangements in relation to Greece and Ireland. Moreover, how and to what extent the two countries were affected by these changes and whether they took advantage or not of the new situation that was created was also demonstrated.

In this respect $\mathrm{I}$ have tried to develop in a convincing way an economic and political periodisation, based on French Regulation School. By this way I tried to complement and extend French Regulation approach of the world development since 1945. Moreover, I demonstrated the different understanding of capitalist dynamism and development by Greece and Ireland and the consequent different political route they followed.

By describing the evolution of Ireland and Greece in the context of the world economy, I argue that national characteristics and experiences have been important in determining the pace by which a country adjusts itself to world changes. A similar conclusion has been drawn by Caloghirou, Voulgaris and Zambarloukos ${ }^{[18]}$, but their analysis mainly concerned the domestic industrial restructuring policies of Greece and Spain and little attention was given to the similar developments in the world context.

Consequently, from the analysis of this research it is evident how Ireland has advanced a more sophisticated understanding of the dynamics of capitalist development in relation to Greece and therefore been able to identify and give preferential assistance to growing sectors (e.g. IT sector). Ireland very early realised the importance of FDI as a key element for the development of their economy and followed a consistent policy in favour of it. On the contrary, Greece has not managed yet to develop a long term strategy in favour of FDI as the different political 
parties that have come into power have adapted different policy stances towards foreign investors.

\section{REFERENCES}

1. Aglietta, M., 1979. A theory of capitalist regulation. The US experience. Translated by Fernbach, D., Calmann-Levy (Ed.)

2. Amin, A., 1997. Capitalism in the Age of Globalization. Zed Books.

3. Amin, A., 1999. An institutionalist perspective on regional economic development. Int. J. Urban Regional Res.. 23 (2): 365-378.

4. Amin, A. and F. Wilkinson, 1999. Learning, proximity and industrial performance: An introduction. Cambridge J. Econ., 23: 121-125

5. Amiti, M., 1998. New trade theories and industrial location in the EU: A survey of evidence. Oxford Rev. Econ. Policy. 14 (2): 54-53.

6. Alogoskoufis, G., Giavazzi, F., Laroque, G. 1995. The two faces of janus: Institutions, Policy Regimes and Macroeconomic Performance in Greece. Econ., 10 (20): 147-192

7. Antonopoulou, S.N., 2000. The process of Globalisation and class transformation in the West. Democracy and Nat., 6 (1): 37-54.

8. Arestis, P. and E. Paliginis, 1995. Divergence and Peripheral Fordism in the European Union. Rev. Soc. Econ., L3 (2): 261-284.

9. Asheim, B., 1996. Industrial districts as Learning Regions: A condition for prosperity. Eu. Planning Stud., 4 (4): 379-397.

10. Atkinson, RD., 2000. Myths of the new economy. New Econ.. 7 (1): 54-58.

11. Barbosa, N. and Louri, H. 2002. On the determinants of multinationals ownership preferences: evidence from Greece and Portugal. Int. J. Ind. Org., 20 (4): 493-515.

12. Barrios, S. Gorg, H and Strobl, E. 2002. Multinationals' Location Choice, Agglomeration Economies and Public Incentives. www.nottingham.ac.uk/economics/staff/details/pap ers/holger14.pdf <http://www.nottingham.ac.uk/economics/staff/det ails/papers/holger14.pdf $>$, access date: June 2005

13. Bonacich, E. and Appelbaum, R. 2000. Behind the Label. Inequality in the Los Angeles Apparel Industry. University of California Press

14. Bevan, A. and Estrin, S. 2004. The determinants of foreign direct investment into European transition economies. J. Comp. Econ., 32 (4): 775-787.
15. Boyer, R., 1990. The Regulation School: A critical Introduction. Translated by Craig Charney, Columbia University Press.

16. Boyer, R., 2000. Is a finance-led growth regime a viable alternative to Fordism? A preliminary analysis. Econ. Soci., 29 (1):111-145.

17. Brenner, R. and M. Glick, 1991. The regulation approach: Theory and history. New Left Rev., 188: 45-119.

18. Caloghirou, Y., Y. Voulgaris and S. Zambarloukos, 2000. The political economy of industrial restructuring: Comparing Greece and Spain. South Eur. Soc. Politics. 5 (1): 73-96.

19. Casstells, M., 1996. The Rise of the Network Society. Blackwell Publishers.

20. Corkill, D. 1999. The Development of the Portuguese Economy: A Case of Europeanization. Routledge

21. Dicken, P., 1992. Global Shift: The Internationalisation of Economic Activity, $2^{\text {nd }}$ (Edn.), Paul Chapman Publishing Ltd.

22. Dicken, P., 1998. Global Shift: Transforming the world Economy. $3^{\text {rd }}$ Edn. Guilford Press

23. Dicken, P., 2003 Global Shift: Transforming the World Economy. $4^{\text {th }}$ Edn., SAGE.

24. Dicken, P., M. Forsgren and A. Malmberg, 1994. The local Embeddedness of Transnational Corporations. In Globalization, Institutions and Regional Development in Europe. Ash Amin and Nigel Thrift, (Eds.). Oxford University Press: Oxford, New York.

25. Dunford, M., 1995. Towards a post-fordist order? Rev. Int. Political Econ., 1.2 (1): 185-204.

26. Dunford, M. and D. Perrons, 1994. Regional inequality, regimes of accumulation and economic integration in contemporary Europe. Tran Ins. Br. Geogr., 19: 163-182.

27. Eichengreen, B. and P. Vazquez, 1999. Institutions and Economic Growth in Postwar Europe: Evidence and Conjectures. www.elsa.berkeley.edu $\leq \mathrm{http}: / /$ www.elsa.berkeley.edu $>$, access date 04/01/2007.

28. Georgopoulos, A. and H. Preusse, 2006. European integration and the dynamic process of investments and divestments of foreign TNCs in Greece. Eur. Business Rev. 18 (1): 50-59.

29. Gorg, H. and F. Ruane, 2000. An analysis of backward linkages in the Irish electronic sector. The Econ. Social Rev., 31 (3): 215-235.

30. Gorg, H. and F. Ruane, 2000. European Integration and Peripherality: Lessons from the Irish Experience. World Economy. 23 (3): 405-421. 
31. Harms, B.J. and T. Knapp, 2003. The new economy: What's New, What's Not. Review of Radical Political Economics. 35 (4): 413-436.

32. Harvey, D., 1995. Globalization in question. Rethinking Marxism. 8: 1-17.

33. Harvey, D., 2000. Reinventing Geography. New Left Rev., 4: 75-97.

34. Harvey, D., 2001. Spaces of Capital, Towards a Critical Geography. Edinburgh University Press.

35. Hellenic Embassy in Dublin-Office of Commercial and Economic Affairs. 2002. The Irish Economic Miracle and the Role of Foreign Investment. (The report is in the Greek language).

36. Hoffman, G.W., 1967. The problem of the underdeveloped regions in southeast europe: A comparative analysis of romania, yugoslavia and greece. Annals of the Association of American Geographers. 57 (4): 637-666.

37. Hudson, R., 1997. Regional futures: Industrial restructuring, new high volume production concepts and spatial development strategies in the new Europe. Regional Studies. 31 (5): 467-478.

38. Hudson, R., 1999. What makes economically successful regions in Europe successful? Implications for transferring success from West to East. Economic Geography Research Group. Working Paper 99/01.

39. Hudson, R., 2002. Changing industrial production systems and regional development in the New Europe. Royal Geographical Society. 262-281.

40. Hudson, R. and A. Williams, (Eds.), 1999. Divided Europe-Society and Territory. Sage Publications.

41. Jessop, B., 1997. Survey Article: The Regulation Approach. J. Political Philosophy. 5 (3): 287-326.

42. King, R. and M. Donati, 1999. The Divided Mediterranean: Re-defining European Relationships. In: Divided Europe-Society and Territory. Hudson, R. and A. Williams, (Eds.). Sage Publications: London.

43. Kourliouros, E., 2003. Economic-noneconomic debate. A radical geographical perspective from the european south. Antipode. 35 (4): 781-799.

44. Leborgne, D. and A. Lipietz, 1991. Two social strategies in the production of new industrial spaces. In: Industrial Change and Regional Development. Benko, G. and M. Dunford, (Eds.). Belhaven P: London.

45. Lipietz, A., 1987. Mirages and Miracles. The Crises of Global Fordism. Translated by David Macey. Verso: London.

46. Lipietz, A., 1997. The post-Fordist world: Labour relations, international hierarchy and global ecology. Rev Int. Political Econ., 4(1): 1-41.
47. Martin, R., 1999. The new Geographical turn in economics: Some critical reflections. Cambridge J. Econ., 23: 65-91.

48. Martin, V., 1999. Globalisation and Economic Analysis. Development and Socio-economic Progress. 23 (75): 62-74.

49. Mavroudeas, S., 2003: Commodities, Workers and Institutions: Analytical and Empirical Problems in Regulation's Consumption Theory. Rev. Radical Political Econ., 35 (4): 485-512.

50. Mjoset, L., 1992. The irish economy in a comparative institutional perspective. National and Economic Social Council: Dublin.

51. Murphy, A., 2000. The Celtic Tiger. An Analysis of Ireland's Economic Growth Performance. EUI Working Paper RSC No. 2000/16. European University Institute. Robert Schuman Centre for Advanced Studies: Florence.

52. Nagy, A., 1999. Porgugal's European Integration and its Effects on her Foreign Trade. Acta Oeconomica. 50 (1-2): 191-222.

53. OECD, 1999. The Globalisation of Industry in the OECD Countries, by Thomas Hatzichronoglou. STI Working Papers, 1999/2. Directorate for Science, Technology and Industry.

54. Pagoulatos, G. and V. Wright, 1999. The Politics of Industrial Privatization: Spain, Portugal and Greece in a European Perspective. Rivista Trimestrale di Diritto Pubblico. 3: 613-662.

55. Perrons, D., 1981. The role of Ireland in the New International Division of Labour: A Proposed Framework for Regional Analysis. Regional Studies. 15 (2): 81-100.

56. Perrons, D., 1986. Unequal Integration in Global Fordism: The Case of Ireland. (Chapter 12). In: Production, Work, Territory: The Geographical Anatomy of Industrial Capitalism. Scott, A. and A. Storper, (Eds.). Allen and Unwin, Boston, London.

57. Perrons, D., 2004. Globalization and Social Change. People and Places in a Divided World. Routledge (Eds.), London.

58. Piore, M. and C. Sabel, 1984. The Second Industrial Divide. Possibilities for Prosperity. Basic Books.

59. Pohjola, M., 2002. The New Economy: Facts, impacts and policies. Info. Econ. Policy. 14: 133-144.

60. Porter, M., 1990. The Competitive Advantage of Nations. THE MACMILLAN PRESS LTD, London. 
61. Sabel, F.C., 1996. Flexible Specialisation and the Re-emergence of Regional Economics. In: PostFordism-A Reader. Ash Amin, (Ed.). Blackwell: Oxford, Cambridge, Mass.

62. Sayer, A. and R. Walker, 1992. The New Social Economy: Reworking the Division of Labour. Blackwell (Eds.).

63. Stenberg, E., 1999. Transformations: The Forces of Capitalist Change. In: Twenty-first Century Economics: Perspectives of Socioeconomics for a Changing World. W.E. Halal and K.B. Taylor, (Eds.). St. Martin's Press, London.

64. Sweeney, P., 1999. The Celtic Tiger: Ireland's Continuing Economic Miracle. $2^{\text {nd }}$ Edn., Oak Tree Press, Dublin.
65. Taylor, P.J., M.J. Watts and R.J. Johnston, Geography/Globalization. www.lboro.ac.uk/gawc /rb/<http://www.lboro.ac.uk/gawc/rb/>, edited and posted on the web on $12^{\text {th }}$ February 2001; last update $6^{\text {th }}$ February 2002. (access date: March 2003) Note: This research bulletin has been published in RJ Johnston, PJ Taylor and MJ Watts (eds), 2002. In: Geographies of Global Change, $2^{\text {nd }}$ Ed., Blackwell, Oxford.

66. UNCTAD, 2002. World Investment Report 2002: Transnational Corporations and Export Competitiveness. (Ed. UN). New York and Geneva 67. The George C. Marshall Foundation www.marshallfoundation.org/about_gem/marshall _plan.htm<http://www.marshallfoundation.org/abo ut_gem/marshall_plan.htm>, access date: June 2007. 